\title{
Reflections on social cohesion in contemporary South Africa
}

\section{[ R E F L E C T IO N S ]}

Social cohesion has become an important construct in South African society in recent years. It has a fairly short history, appearing predominantly in the post-apartheid period and more specifically in the period around 2012 when the Department of Arts and Culture (the government department responsible for drafting the social cohesion strategy) hosted a social cohesion summit and adopted social cohesion and nation building strategy (DAC, 2012). In 2014 a social cohesion summit was held and a second report back on the 2014 social cohesion summit was then held in 2015 along with other related activities such as presentations to parliament on social cohesion by the Department of Arts and Culture. Since this process began the concept has become particularly commonplace and whilst it is used by many across government and non-governmental sectors I want to concentrate here on the ways in which it is used by the Department of Arts and Culture in official strategies and formal speeches. Social cohesion is connected to several related concepts which I will only be able to mention briefly in order to consider why social cohesion may have emerged as important in this moment. Most significantly, I want to suggest that the use of social cohesion at this point in time should not be unproblematically celebrated. Rather we need to question why we want social cohesion, in what forms, and what it might offer to whom at this moment in South African history.

Tracing the origins of social cohesion shows that it is a concept that has roots beyond South Africa. Internationally, social cohesion has emerged out of the literature on social capital (see Portes, 2000 for an overview; also Putman 1993, 2001). In this context social

\author{
Ingrid Palmary \\ African Centre for \\ Migration \& Society, \\ University of the \\ Witwatersrand, \\ Johannesburg \\ Ingrid.Palmary@wits.ac.za
}


cohesion has been understood to be just one aspect of social capital. Authors writing in this tradition have focussed on how social cohesion may be improved (usually among people living within defined geographical spaces as in neighbourhoods or communities (see Kawachi and Berkman, 2000; Forrest and Kearnes, 2001)) and what the positive outcomes may be for those with higher levels of social cohesion (see Forrest and Kearnes, 2001). However, two points that are evident in this literature will form the basis of my reflections here. Firstly, this literature recognises that social cohesion (and indeed the broader construct of social capital) may not always be positive. The oft cited example of the mafia is an illustration of how a group may display all the components of high social cohesion but to negative effects (see Greeley, 1997). Secondly, in the global literature, social cohesion has not been linked to nation building in the way it has in South Africa and so I will consider the consequences of this further. Connected to this, social cohesion has not always been considered as something that the State can, or should, promote. These points are the focus of my reflections here.

Let me turn then to the ways in which social cohesion has been taken up in South Africa. A review of the relevant documents and speeches on social cohesion immediately shows that it is treated as synonymous with nation building. The title of the draft 2012 policy was A national strategy for developing an inclusive and cohesive South Africa. However, in the body of the report where the term social cohesion appears it is referred to every time as social cohesion and nation building and the document itself is referred to as a strategy for social cohesion and nation building. Thus, comparing the South African approach to other contexts we already see that social cohesion in South Africa is uniquely understood as a project of nation building whereas internationally social cohesion is seen as something more localised and where it is connected to the State it is usually as a reflection of how people in a country feel about the State (rather than each other).

In many ways, this focus on nation building should not be surprising. Concerns about the unity of South Africans have been persistent in recent history and the relatively new democratic State (and associated South African identity) is perhaps more fragile than ever. However, the ideas associated with social cohesion have a longer trajectory. In the immediate lead up to democracy the term reconciliation was used in a similar way to social cohesion even if it was designed to reflect a more specific moment of peace building in the immediate aftermath of war. In other historical moments nation building has been a worrying phenomenon even if it employed the same rhetoric of social cohesion and building communities. For example, Lubbe (1991) notes the drive to increase cohesion among white South Africans through the 1929 elections which then became known as the Swart gevaar volksraadverliesing [Black danger municipal election]. She, like other authors show how otherwise hostile white groups in South Africa - still with the memory 
of the Anglo Boer war fresh in their minds - could be united through the use of a sense of crisis and threat. In a similar way, Cock (1994) notes the ongoing militarization of white men through the promotion of identification with the nation as defined under apartheid. Thus when social cohesion becomes aligned to nation building there is ample evidence that positive effects need not always be the outcome and for the present social cohesion strategy this means that a number of consequences need to be fleshed out.

What is significant in the current social cohesion strategy is that not only does it explicitly distance itself from this version of exclusionary nationalism but social cohesion and nation building is seen as precisely a response to, and remedy for, the effects of a racist and otherwise exclusionary past. Indeed, in the introduction it is stated that the precise purpose of the social cohesion and nation building strategy is to move away from the ethnic and racial divisions that have been created in South Africa. It states that: "the colonial practice of enlisting cultural diversity as a justification for inequality, exclusion and the systematic division is rejected as conceptually inappropriate and ethically undesirable" (section 10).

In contrast the problem statement that forms the basis for the social cohesion and nation building strategy states that: "The challenge, therefore, is to enhance social cohesion and foster the development of a shared South African identity which incorporates diversity in a democratic dispensation. This relates directly to the translation of the rights and responsibilities of both the State and its citizens into social reality" (section 5).

A couple of things are clear from these extracts. Most notably, it is taken for granted that social cohesion and nation building are part of the same project. At no point in the document is the use of the two terms together explained and, given that these two concepts have not been used synonymously in other literatures on social cohesion this is curious. As a consequence, the proposed interventions are a rather unusual and not always complimentary combination of ideas, including for example, addressing economic injustices alongside improving national pride and promoting national symbols such as the flag or the sports teams. One of the key outputs of the social cohesion and nation building strategy involves promoting heritage and culture and proposed activities include making sure that schools fly the national flag and that people support their sports teams (Jack, 2015). This sits alongside the need to ensure economic equality and improve the delivery of State services.

And yet thirty years of (mostly feminist) research and writing on nationalism have indicated how important it is to be sceptical of some forms of banal nationalism (Billig, 1995). To say that nations are invented is now accepted (see Anderson, 2006; Hobsbawm, 2012). McClintock (1993) has made the often cited point that all nationalisms are invented

PINS [Psychology in Society] 49 • $2015 \mid 64$ 
all are gendered and all are dangerous. Taking for granted that their invention does not need to be argued I want here to focus on how the cohesive South African nation that is invented through the social cohesion and nation building strategy is gendered and potentially dangerous.

The gendered nature of the document is most evident in its affective and feminised tone. The title of the strategy is Creating a caring and proud society. In the introductory section entitled vision emphasis is put on the principle of Ubuntu which it defines as: "[A] social humanism of interpersonal care, sharing and a commitment to the greater social good. It posits the individual human being as a social construct in a public culture of human reciprocity and solidarity" (section 3 ).

These are very difficult principles to critique given how seemingly self-evidently positive they are. However, Ahmed (2003) has noted the ways in which love can justify violence and animate hate. She notes that hate motivated by love functions "as a narrative of entitlement (it names those who worked to create the nation and who work on the land to make the nation) as well as a narrative of displacement (it names those who seek to take the benefits of that work away) (Ahmed, 2003: np)". In its connections to nation building and citizenship social cohesion is put forward as a project of emotional work as much as one of structural change. In doing so, love of the nation slides into the kind of "exclusion through love" that Ahmed describes. What is most notable in the strategy is that after the first reference to the constitution that reminds us that South Africa belongs to all who live in it, all other references are to citizens. This reminds us how the feminised language of love and care is frequently mobilised in the masculinist project of nation building (see McClintock, 1997; Yuval Davis, 1997). Following Ahmed (2003), in the social cohesion and nation building strategy, there are moments where the language of compassion, care, pride and justice that is used in the policy can cover for forms of exclusion and injustice at the moments where they emerge as being in the interests of nation building.

This is indicated in the following extracts from the strategy document: "The preamble to the Constitution of South Africa declares: 'We the people of South Africa ... believe that South Africa belongs to everyone who lives in it, united in our diversity'"... This is reiterated in the motto on the National Coat of Arms by the /Xam expression !ke e: /xarra //ke which literally means "diverse people unite". It thus enjoins the citizens to unite in a sense of belonging and pride (section 3 ).

What is intriguing in this segment of the vision of the strategy is that it moves from a constitutional reference to everyone living in South Africa to a need for unity in citizenship. This move is evident throughout the policy which shifts from statements 
about justice and equity to citizenship taking for granted that these are connected. Thus whilst there are moments where the document addresses South Africa as a geographical space, there is also a constant reference to citizens as the ones that need cohesion. In its claim to foster love, pride, justice and redress the policy thus creates it own exclusions by failing to recognise one aspect of diversity in South Africa namely the diverse citizens who live in it. For example, it states: "[T]he constitution and its Chapter Nine Institutions have laid the foundations for an inclusive and just relationship between the citizens and the state at different levels of government" (section 3).

Of course the reach of the Chapter 9 institutions goes beyond the protection of citizens and this is most evident in the way, for example, the human rights commission has investigated violence against foreigners in South Africa. In the strategy however, social cohesion is conceptualised as centrally about the making of citizens and the invention of a citizen identity.

This cohesion creates non-citizens in the way inclusion is framed. In a context of widespread antagonism and violence against foreign nationals in South Africa one wonders why citizenship should be the basis for social cohesion. Indeed, violence against foreigners may well be an example of precisely the kinds of negative social cohesion mentioned in the literature on social capital, where groups of people defined by a sense of sameness work together to negative effects. It is not that the document ignores violence against foreigners. There is passing reference in a bullet point that says South Africans should welcome and integrate foreigners (section 6). However not only is this sentence swamped by the nationalist imagery of the strategy it acknowledges foreigners only in so far as they are different to citizens.

Furthermore, there is direct reference to violence against foreigners (in section 5). However, it is only understood to: "[I]ndicate a breakdown between the government and the citizens, on the one hand, and the disregard for peaceful democratic action and human rights values among citizens, on the other" (section 5).

Thus citizenship, the promotion of nationalism through symbols and sense of identity are seen as solutions rather than as part of the problem. It may well seem that my critiques of the focus on citizenship and nation building are overstated. After all South Africans are very divided and some level of cohesiveness would likely be positive even if it is produced through identification with sports teams and flags. However, my anxiety about this promotion of nationalism comes from research that I have conducted with perpetrators of violence against foreigners. What was noteworthy in this research was how the sense of national pride, which in itself is connected to notions of national entitlement has made the violence meted out on foreigners something that is defined by 
those who organized the violence as an act of love (love of community, love of the nation and love of other South Africans). Indeed, the language they adopted was very similar to the language of the social cohesion and nation building strategy and is indicative of how easy it is for nation building language to be co-opted into a violent agenda.

One of my respondents in the research noted how the violence against foreigners was really motivated through love. He told me that: "We had to battle for so many years against apartheid. Now we defeated that part and now we are in the process of rebuilding the country to trust each other, to get to know each other get to tolerate each other, to live with each other, to get to trust each other ... So we ... want us to heal and without any disturbance from them".

We see here a seemingly contradictory idea of their violence being driven by a desire for healing, trust and peace in contrast to the intolerance and innate violence of foreigners. Ironically, when I pushed them about why they didn't then attack white South Africans, the sense that South Africa needed racial reconciliation was dominant and rather it was those that move that were seen as damaging community. In a context where violence against foreigners is seen as an act of reconciliation and care, a social cohesion policy that reinforces this however unintendedly is cause for concern. Arguably, violence in the name of freedom, love and protection of the nation as we see in the violence that takes place against foreigners is indeed an act of social cohesion with negative effects. It reflects a cohesive community acting in solidarity and with a common purpose and sense of values. Something that the social cohesion strategy very explicitly attempts to promote. As another respondent who had led attacks on foreigners said to me: "The migration department once told them that to say your rights are very limited despite that South Africa has got freedom, that freedom is not yours, it is a South African freedom."

\section{Conclusions}

In this reflective piece I have tried to make sense of the otherwise rather curious conflation of social cohesion with nationalism and citizenship in the social cohesion strategy. Perhaps the greatest puzzle that remains is how it can be taken for granted that the two concepts are synonymous. In many ways that this has been the case for the four years since the drafting of the social cohesion strategy without much critique suggests that the idea of citizenship being the basis for positive relationships is in fact more entrenched in South African society than many (including those who drafted the strategy who lament the absence of a national identity) realise. However, I have raised several cautions in this piece. The first is that regardless of whether social cohesion is seen to be about nation building or not, it clearly is not always a positive thing and can be used for exclusion and violence. When it is connected to forms of banal nationalism it would seem inevitable that non-citizens become the target of this violence. It is precisely 
the naturalization of citizenship identity that allows violence against foreigners to be recast as an act of love, care and building a community rather than one of violence and exclusion. Whilst the tone of the social cohesion strategy appears to be unquestioningly positive, the connections to nation building and citizenship provide worrying clues as to how this strategy could be used in ways that foster ongoing violence and social exclusion.

It would seem that the timing of the social cohesion strategy also coincides with a moment in history when the miracle transformation to democracy has lost some of its shine and there is increasing frustration with the slow pace of social change in South Africa. In this political moment, nation building rhetoric becomes potentially explosive. For meaningful social cohesion to occur in South Africa it needs to be disconnected from citizenship and we need to question what more inclusive forms of social cohesion might look like, how it can be accomplished and what if any role the State should play in this.

\section{References}

Ahmed, S (2003) In the name of love. Borderlands e-journal, 2(3).

Anderson, B (2006) Imagined communities: Reflections on the origin and spread of nationalism. London: Verso.

Billig, M (1995) Banal nationalism. London: Sage.

Cock, J (1994) Women and the military: Implications for demilitarization in the 1990s in South Africa. Gender \& Society, 8(2), 152-169.

Department of Arts and Culture (2012) !Ke e: /xarra //ke: Creating a caring and proud society a national strategy for developing an inclusive and a cohesive South African society. Pretoria: DAC.

Forrest, R., \& Kearns, A (2001) Social cohesion, social capital and the neighbourhood. Urban studies, 38(12), 2125-2143.

Greeley, A (1997) Coleman revisited: Religious structures as a source of social capital. The American Behavioral Scientist, 40(5), 587.

Hobsbawm, E J (2012) Nations and nationalism since 1780: Programme, myth, reality. Cambridge: Cambridge University Press. 
Jack, V (2015) Briefing to the portfolio committee social cohesion programme. https://pmg.org.za/files/150324Social_Cohesion.ppt. Accessed 3 September 2015.

Kawachi, I \& Berkman, L (2000) Social cohesion, social capital, and health, in Berkman, L \& Kawachi, I (eds) Social epidemiology. Oxford: Oxford University Press (pp 174-190).

Lubbe, H (1991) Vergeet die arbeiders en wen die 'kleurlinge':

Die 'swart gevaar'- propaganda in kaapland gedurende die parlementêre verkiesingstryd van 1928 tot 1929. Kronos, 18, 15-28.

McClintock, A (1993) Family feuds: Gender, nationalism and the family.

Feminist Review, 4, 61-80.

Putnam, R (2001) Social capital: Measurement and consequences.

Canadian Journal of Policy Research, 2(1), 41-51.

Putnam, R D (1993) The prosperous community: Social capital and public life, in Blaire, K, Almjeld, J \& Murphey, R (eds) Cross currents: Cultures, communities, technologies. Boston: Wadsworth (pp 249-257).

Yuval-Davis, N (1997) Gender \& nation. London: Sage. 